\title{
14 Public Health and Capitalism in Japan
}

\author{
The Impact of Labour Market Challenges and Welfare on \\ Public Health
}

Saori SHIBATA

\begin{abstract}
Attempts by the World Health Organization (WHO) and national governments to provide direction on public health have been affected by the socio-economic institutions present in different countries. The different national models of capitalism that are in place in different countries have had an impact upon the capacities of these countries to deal with public health during the COVID-19 pandemic. This chapter introduces the relationship between public health and national models of capitalism by looking at the case of Japan, and argues that the problems faced by people as a result of Japan's neoliberalized labour market and welfare system have created a number of obstacles to the successful management of the pandemic.
\end{abstract}

Keywords: public health, Japan, capitalism, labour market, neoliberalism, COVID-19

The World Health Organization (WHO) has received much criticism with regard to the legitimacy and effectiveness of its handling of the COVID-19 pandemic, with many political leaders being especially critical. This has made more evident than ever the challenges that international organizations, such as the WHO, face as they seek to coordinate international communities (NHK 2020). The attempts by the WHO, as well as by national governments, to provide direction on public health have been affected by the socioeconomic institutions present in different countries. The national models of capitalism in place have had an impact upon the capacities of different countries to deal with public health.

Van der Veere, Anoma P., Florian Schneider, and Catherine Yuk-ping Lo (eds), Public Health in Asia during the COVID-19 Pandemic: Global Health Governance, Migrant Labour, and International Health Crises. Amsterdam, Amsterdam University Press 2022 DOI: 10.5117/9789463720977_CH14 
This chapter first introduces the relationship between public health and national models of capitalism. Here, it highlights the impact of different socio-economic institutions (especially the labour market and welfare system) upon public health. After this, the chapter demonstrates how workers' problems are intertwined with their health. The chapter then demonstrates how challenging it has been for the WHO to address the pandemic and public health in different nations. This has been challenging because of how its attempts to deal with the pandemic have been influenced by the socio-economic institutions that are present in different nations.

In some nations, these socio-economic institutions include deep-rooted labour market problems that have been produced through an ongoing process of neoliberalization. This is the case, for instance, in Japan. The chapter then goes on to show that Japan's neoliberalized welfare system also impacts public health and increases social and health risks for many members of the public. Finally, it argues that the problems people face in the labour market and the welfare system have created a number of obstacles to the successful management of the pandemic and the implementation of necessary public health measures.

\section{WHO, Capitalism, and Public Health}

The national model of capitalism in place in any one country and global capitalism as a whole both significantly influence how public health is achieved (Sell and Williams 2020; Hernández-Álvarez et al. 2020; Hunter and Murray 2019). Many national models of capitalism function in states with a substantial welfare system. However, this system has proven unable to remove the market logic from public health in general, as well as in terms of access to healthcare services and essential medicines (Sell and Williams 2020, 4). Neoliberalism, and the associated preoccupation with market fundamentalism, has seen a prioritization of profit-seeking and austerity. It has also made work more precarious, resulting in growing economic insecurity for workers. This market logic, and particularly the drive for austerity, has led to widespread cutbacks in health services as well as market-driven reforms that have limited the availability of healthcare. During the ongoing COVID-19 pandemic, these conditions have created the potential for devastating consequences to public health (Sparke 2020, 1). Health is not an accidental outcome, but is 'shaped by people's location in terms of generational wealth, poverty and income inequalities within a wider 
national and global structure of accumulation' (Sell and Williams 2020, 4). As An and Tang $(2020,793-796)$ highlight, both institutional infrastructure and system capacity influence pandemic crisis management. Crucial factors for pandemic management include the capacity of public health institutions, healthcare facilities, medical services, information management technology, and regulatory systems.

This chapter argues that in order to understand the impact of the COVID-19 pandemic upon public health in Japan, we need to consider the country's institutionalized structures of inequality. In Japan, the medical and healthcare system, welfare system, health insurance system, and the labour market system are key socio-economic institutions that together have largely determined the extent to which the pandemic and public health have been handled. In other words, the model of capitalism present in Japan, as well as the existing patterns of social inequalities in public health, have had a crucial influence on how the pandemic has been managed.

The impact of the pandemic has depended on wealth, poverty, and income inequalities, within a wider national structure of capital accumulation. For instance, in some nations markets fail to deliver access to healthcare to all of the population when this access is dependent upon the ability to pay health insurance contributions, or when people are denied access to basic healthcare. Labour market conditions can also impact how the pandemic affects people. If people lose their jobs and become unemployed during a public health crisis, this can present significant risks to them and their families. Where national welfare systems provide insufficient coverage, this can mean that vulnerable people bear considerable risks during a pandemic (see also Nguyen's contribution in this volume).

The WHO has sought to advise national governments about responding to the pandemic by issuing a range of guidelines and measures relating to public health, local communities, domestic violence, quarantine, food safety, and safe workplaces (WHO 2020a). However, these guidelines and measures have so far had limited effects. For example, the advice given by the WHO has had a limited effect on securing public health in Japan. This is in large part due to the WHO's limited ability to deal with questions such as job security and welfare provisions, which play an essential role in addressing public health. In particular, socio-economic institutions have had a considerable effect on health governance and the unequal ways in which people in Japan have experienced the COVID-19 public health crisis. 


\section{Labour Market Challenges and Public Health}

A number of labour market reforms have sought to address problems faced by workers in Japan. These include the structural reforms and Work Style Reform (hatarakikata kaikaku) that were part of the so-called 'Abenomics' policies adopted by former Prime Minister Shinzo Abe. These reforms involved an increase in the minimum wage, an attempt to move workers on non-regular contracts to regular contracts, and efforts to encourage a shortening of working hours (Shibata 2020). However, the Abe government's priority has been the pursuit of labour market flexibility. This means that the proportion of non-regular workers, or those who do not have long-term employment security, within Japan's labour market has remained high, amounting for nearly $40 \%$ of the total workforce. The precarious situation faced by many non-regular workers has not improved under Abenomics (Shibata 2020).

The increase in the number of non-regular workers does not necessarily mean an increase in inequality; not all non-regular workers are precarious, and the employment situation surrounding non-regular workers has become complicated (Imano 2020). Nevertheless, it is under the current labour market conditions that non-regular workers were the first group of workers to face dismissals as a result of the COVID-19 pandemic. Such dismissals were termed 'corona dismissals' by the media, who announced a 'significant unemployment era' (Toyo Keizai Online 2020). These dismissals have seen the number of unemployed grow from 1.5 million at the end of 2019 to almost 2 million in May 2020 (Nihon Keizai Shimbum 2020). This also resulted in a rise in the unemployment rate, from $2.4 \%$ in 2019 to $3.1 \%$ in October 2020 (MHLW 2020).

In addition, workers were denied access to, or received reductions in, the 'absence allowance' that they were supposed to receive from employers. This 'absence allowance' was a government scheme that promised $80 \%$ of wages to staff who were unable to work because COVID-19 had forced the temporary closure of the companies where they worked. The government also provided other financial support, but the absence allowance was the most comprehensive financial support available, covering the majority of workers who were not able to work as a result of COVID-19. The allowance promised to guarantee workers' wages during the pandemic. Despite this guarantee, $24 \%$ of non-regular workers reported that their employers refused to provide the allowance (Nishinihon Shimbum 2020). Not receiving this allowance can impede workers' access to medical and healthcare services, because this access is dependent on their ability to pay healthcare insurance contributions. It can particularly lead to difficulties accessing medical 
healthcare services for foreign workers, female workers, and precariously employed non-regular workers. In particular, foreign workers faced a higher risk of losing their jobs and were more likely to receive low wages, both of which represent obstacles to public health. These workers are often ineligible for Japan's health insurance system while also lacking the informal family networks that offer an alternative means for securing healthcare and social support (Sawada 2018). While these problems existed before this, the pandemic has magnified them.

In different nations including in Japan, gender-based discrimination has intensified during the pandemic. The WHO has used its briefing papers to address the potential for increased domestic violence against women during the pandemic (WHO 2020b). Although this has represented an important source of advice, it is the Japanese government that has had to take the initiative and address nationally specific issues in terms of gender inequality. In Japan, there is a large disparity between male and female workers' wages and employment status. Female workers have tended to be most burdened with home-making and domestic care for family members. This has led to a decline in female workers' participation in the labour market and a corresponding increase in the degree to which women are dependent upon their husbands or partners for health and medical care. This has put single female workers at a considerably higher public health risk.

Female workers appear to have borne the brunt of pandemic-related job losses (Ishibashi and Nakafuji 2020). The number of jobs lost by female workers is significantly higher than that of male workers. For example, $11.4 \%$ of female workers lost their jobs between December 2019 and August 2020, compared to $0.8 \%$ of male workers during the same period (Statistics Bureau of Japan 2020). This may have contributed to a reported recent rise in suicide among women. According to an August 2020 report on suicide by Japan's National Police Agency, the number of women who committed suicide rose by $51 \%$ between April 2020 and August 2020, from 442 to 669 , whereas the number of men committing suicide rose by $17 \%$ (National Police Agency 2020). The WHO needs to recognize such nation-specific inequalities as crucial for public health policies.

\section{The Transformation of the Japanese Welfare System and Challenges to Public Health}

Some observers have highlighted that during the initial stages of the COVID-19 pandemic Japan handled the coronavirus relatively well, maintaining 
a low number of infections and deaths in comparison to other countries. It did this despite being a densely populated country with a large elderly population (Iwasaki and Grubaugh 2020; Tashiro and Shaw 2020). In seeking to identify reasons for this relative success, commentators have pointed to Japan's culture, its medical and healthcare systems, the level of sanitation, citizens' behaviour, and the 'cluster approach' used (Tashiro and Shaw $2020,3)$.

However, it is not universally agreed that Japan has handled the pandemic entirely effectively, or that it has done so for these reasons. Crump and Tanimoto, for instance, have argued that Japan's situation worsened due to a mismanagement of the pandemic, lack of adequate personal protection equipment, and incompetence among hospital personnel (2020, 2). Similarly, An and Tang argue that Japan has mismanaged the pandemic, highlighting the country's lack of pre-established institutional infrastructure, the lack of legal means to impose substantive penalties, and its limited testing capacity in comparison to other East Asian polities (2020, 795-797). In contributing to this debate, this chapter leans towards the more critical interpretations, but in doing so it seeks to draw attention to the declining quality of welfare provision in Japan, arguing that this has been a decisive factor in explaining how the pandemic has been managed.

The Japanese welfare system introduced a universal medical insurance system in 1961. There was a stable labour market during the 196os, 1970s, and 1980 s. This was characterized by high levels of long-term employment (especially among men) and meant that Japan witnessed an increasing number of workers and increasing insurance contributions. This enabled the state to create a stable welfare system, including a well-functioning public health system. Migrant workers are also covered in this public health system. However, from the 1990s onwards, the neoliberalization of Japan's socioeconomic institutions has progressed steadily. This has been accompanied by a greater emphasis upon individual responsibility for health, including through the privatization (or partial privatization) of health, medical, and elderly care. The government raised insurance premiums from $20 \%$ to $30 \%$ in 2002. In 2011, it reduced the breadth of insurance coverage as part of a gradual increase in the privatization of public hospitals (Ogasawara 2018, 127). Moreover, since the bursting of Japan's so-called 'bubble economy' in 1991, it has experienced low economic growth and economic recessions. This has had a knock-on effect, posing problems for those who have difficulties paying, or are unable to pay, insurance contributions.

As a result, the number of people who are covered by the health insurance scheme has declined from $126,907,000$ people in 2010 , to $125,877,000$ 
persons in 2017 (MHLW 2018). In particular, there has been a significant decline in the number of people who are covered by the national health insurance, which also tends to cover non-regular workers. The number of people covered by this has fallen from $38,769,000$ people in 2010 to $31,475,000$ people in 2017 (MHLW 2018). This is also closely related to the increased number of non-regular workers in the labour market in Japan because the monthly contribution for national health insurance can be a heavy burden for people with low monthly incomes, taking nearly $20 \%$ of their wages (Sato 2014). The rising numbers of non-regular workers, including migrant workers who receive lower wages, face difficulties in paying their health insurance contributions. Moreover, according to Kin (2015), many employers have gradually shifted to non-regular workers who work for shorter hours. This way, employers can avoid paying the costly employers' contributions towards the health insurance of their employees. This trend for increasing non-regular employment will translate into public health deficiencies. During the COVID-19 pandemic, these risks have become more visible.

As part of the state of emergency introduced in Japan in early 2020, the government announced that it would provide 100,000 yen (or around US\$ 920) for every person in the country, including migrant workers and foreign students. However, this money has only been made available for those who had their address registered with their municipal government (Tokyo Shimbum 2020a; 2020b). This stipulation has meant that the government has effectively denied access to financial support for those most vulnerable, especially the homeless. In Japan, support for homeless people has been left to voluntary citizens' groups, reflecting the inadequate nature of public health provision for the homeless (Inaba 2014).

As this chapter has argued, the WHO's one-size-fits-all approach to giving advice risks being ineffective. For example, in spite of the pandemic the Japanese government has decided to continue cuts to the 'public assistance system' (seikatsu hogo seido) that have been ongoing since 2018. This public assistance system guarantees the minimum standard of living for those who have difficulties in making a living. This system provides financial support to enable people to have minimum living expenses (Ministry of Health, Labour and Welfare 2021). The next round of cuts has been announced for October 2020, despite the clear risks to public health these reductions will bring about during the pandemic (Kyodo 2020). The effect will be that $67 \%$ of households who receive the benefits will experience a reduction in financial support, which will worsen accessibility to medical care for those on benefits. 
While foreign residents with permanent residency or a settlement visa are also covered by this benefit scheme, it excludes migrant workers who are only permitted to live in Japan for a fixed term. As such, the availability of these benefits is neither sufficient nor comprehensive, something which further endangers impoverished households that are already vulnerable during public health crises such as the COVID-19 pandemic. In particular, migrant workers who have lost their jobs during the COVID-19 pandemic, and who are not entitled to these benefits, can suffer significantly as a result of their income loss.

Obstacles also exist for those who are entitled to access public health schemes. A number of companies - known as 'black companies' (burakku kigyō) - have a practice of registering employees as self-employed in order to deprive workers of their rights to minimum wage entitlements, overtime payments, the national insurance scheme, health insurance contributions, and medical care. Many migrant workers tend to suffer from this kind of exclusion, even though they are entitled to health insurance. This is compounded by the fact that workers on low pay and with insecure employment contracts have already faced considerable obstacles since before the pandemic began.

\section{Conclusion}

The guidance that has been issued by the WHO represents an important step in making public health recommendations for national governments. A key limitation of this guidance, however, is its scope. The WHO does not address nation-specific socio-economic institutions that have a large impact on public health. This chapter suggests that, in the context of Japan, we have to consider the effects of the ongoing neoliberal reforms across Japan's labour market and public health system. Japan has maintained a relatively low rate of infection, especially in comparison to Western Europe and the United States. However, more adequate employment protections and a comprehensive insurance system would have led to more effective management of the pandemic and long-term maintenance of public health. As the risk of infection has continued into 2021, a rise in unemployment and the fact that a substantial portion of the working population remains in low paid jobs hamper measures to secure public health. As this chapter has shown, the labour market, welfare provision, and public health are mutually dependent upon each other. Social inequality is a public health matter. 


\section{References}

An, Brian Y., and Tang Shui-Yan. 2020. 'Lessons from COVID-19 Responses in East Asia: Institutional Infrastructure and Enduring Policy Instruments.' American Review of Public Administration vol. 50, no. 6-7: 790-80o. https://doi. org/10.1177\%2Fo275074020943707.

Crump, Andy, and Tanimoto Tetsuya. 2020. ‘Covid-19:Japan's Success despite Inept Bureaucracy and Incompetence.' QJM: Monthly Journal of the Association of Physicians vol. 113, no. 7: 455-456. https://doi.org/10.1093/qjmed/hcaa181.

Hernández-Álvarez, Mario, Juan Carlos Eslava-Castañeda, Liliana Henao-Kaffure, José Orozco-Díaz, and Luis Edgar Parra-Salas. 2020. 'Universal Health Coverage and Capital Accumulation: A Relationship Unveiled by the Critical Political Economy Approach.' International Journal of Public Health vol. 65: 995-1001. https://doi.org/10.1007/s00038-020-01437-9.

Hunter, Benjamin M., and Susan F. Murray. 2019. 'Deconstructing the Financialization of Healthcare.' Development and Change vol. 50, no. 5: 1263-1287. https:// doi.org/10.1111/dech.12517.

Imano, Koichirō. 2020. 'Seiki/hiseiki rōdō' [Regular/Non-regular Work].' Nihon Rōdō Kenkyū Zasshi vol. 717: 14-17. https://www.jil.go.jp/institute/zassi/backnumber/2020/04/pdf/o14-017.pdf.

Inaba, T. (2014) Seikatsu Hogo kara Kangaeru [Think from Public Assistance]. Tokyo: Iwanami Shinsyo.

Ishibashi, Mari, and Nakafuji Rei. 2020. 'Women Bear Brunt of Japan's Pandemic Job Losses.' Nikkei Asia, 7 September. Accessed ${ }_{15}$ February 2021. https://asia.nikkei. com/Spotlight/Datawatch/Women-bear-brunt-of-Japan-s-pandemic-job-losses.

Iwasaki, Akiko, and Nathan D. Grubaugh. 2020. 'Why Does Japan Have so Few Cases of COVID-19?' EMBO Molecular Medicine vol. 12, no. 5: e12481. https://doi. org/10.15252/emmm.202012481.

'Kanzen shitsugyōsha, yuruyakani zōka: gogatsu no kyūgyōsha nao 423-man-nin [The Number of Unemployed is Gradually Increasing: The Number of Workers who are Absent during the Corona-period still Remains 4.23 Million People].' Nihon Keizai Shimbum, 30 June. Accessed 15 February 202. https://www.nikkei. com/article/DGXMZO6o958420QoA630C2EE80oo/.

Kin, Meichu. 2015. 'Hiseikikoyō zōkano yō'inn toshite no shakai hokenryō jigyōnushi futan no kanōsei [The Potential Social Insurance Contribution of Employers as a Cause of the Increased Number of Non-regular Workers].' Nihon Rōdō Kenkyū Zasshi vol. 659 (June): 27-46. https://www.jil.go.jp/institute/zassi/ backnumber/2015/06/pdf/o27-046.pdf.

Kyodo. 2020. ' $67 \%$ setai no seikatsu hogohi, gengaku e [67\% of the Recipient Households Face Reduction of Livelihood Protection Benefits].22o2o. Kyodo, 
2 September. Accessed 15 February 2021. https://this.kiji.is/6738269616018729 $93 ? \mathrm{c}=39546741839462401$.

Ministry of Health, Labour and Welfare (MHLW). 2018. 'Shakai-hoken dai-issho iryō hoken [Social Insurance, Chapter 1 Health Insurance].' Figure 5-1. Accessed 15 February 2021. https://www.mhlw.go.jp/toukei/youran/indexyk_5_1.html.

- 2020. 'Roudouryoku chōsa 2020-nen 11-gatsu kekka [Labour Force Survey November 2020 Report].' Accessed 15 February 2021. https://www.stat.go.jp/ data/roudou/sokuhou/tsuki/index.html.

—. 2021. 'Seikatsu hogo seido [Public Assistance System].' Accessed 15 February 2021. https://www.mhlw.go.jp/stf/seisakunitsuite/bunya/hukushi_kaigo/seikatsuhogo/ seikatuhogo/index.html.

National Police Agency. 2020. 'Reiwa 2-nen no jisatushasū ni tsuite [2020 Monthly Number of Suicides].' Accessed 15 February 2021. https://www.npa.go.jp/news/ release/2020/20200907001.html.

NHK. 2020. "WHO ha kōshū eisei yori seiji o yūsen" beikokumushō ga kenshō no kangae ["WHO Prioritized Politics over Public Health": The Department of State of the US Considers Verification].' NHKNews Web, 11 April. Accessed 15 February 2021. https://www3.nhk.or.jp/news/html/20200411/k10012381681000.html.

Ogasawara, Nobumi. 2018. 'Shinjiyūshugiteki iryō kaikaku ni okeru Kankoku to Nihon no hikaku kenkyū [Comparison between South Korea and Japan on Neoliberal Medical Care Reform].' Iryō Fukushi Seisaku Kenkyū vol 2, no. 1: 113-136. https://ci.nii.ac.jp/naid/130007623126/.

Satō, Shigeru. 2014. 'Shakai hoshō de kaette mazushiku naru!? [Social Insurance Scheme impoverishing us more!?]' imidas, 28 December. Accessed 15 February 2021. https://imidas.jp/jijikaitai/f-40-109-14-11-g554.

Sell, Susan K. and Owain D. Williams. 2020. 'Health under Capitalism: A Global Political Economy of Structural Pathogenesis.' Review of International Political Economy vol. 27, no. 1: 1-25. https://doi.org/10.1080/og692290.2019.1659842.

Shibata, Saori. 2020. Contesting Precarity: The Rise of Nonregular Workers and the New Policy Dissensus in Japan. Ithaca, New York: Cornell University Press.

Tashiro, Ai, and Rajib Shaw. 2020. 'COVID-19 Pandemic Response in Japan: What is Behind the Initial Flattening of the Curve?' Sustainability vol. 12, no. 13:5250. https://doi.org/10.339o/su12135250.

The Japan Times. 2020. 'Over 50,00o Workers in Japan Dismissed Due to Pandemic.' 2 September. Accessed 15 February 2021. https://www.japantimes. co.jp/news/2020/o9/o2/business/economy-business/5000o-dismissed-japanpandemic/.

Tokyo Shinbum. 2020a. 'Houmuresuheno jyuumanenkyuufukin, kosekikatsuyou mitomezu: shibuyaku no teiann ni soumusyou "jyuumin touroku de" [Homeless Are Not Allowed to Use their Family Registration to Apply for 100,000 Yen 
Allowance: Ministry of Communication and International Affairs Insist on 'residency Registration" to Shibuya ward head's suggestion]'. Tokyo Web, 18 June. Accessed 1 January 2021. https://www.tokyo-np.co.jp/article/36339

—. 202ob. 'Hōmuresu e no 10-man-en kyūfukin, koseki katsuyō mitomezu: Shibuyaku no teian ni Sōmushō "jūmin tōroku de" [Homeless People not Allowed to use Family Registration to Apply for 100,000 yen Allowance: Ministry of Communication and International Affairs insists on 'Residency Registration' to Shibuya Ward Suggestion].' Tokyo Shinbum, 18 June. Accessed 15 February 2021. https://www.tokyo-np.co.jp/article/36339.

Tomokuni, Hisashi. 2020. “'Chokin kuzushiteiru ga...” daikigyō no hiseiki kuni no shien okizari ["I have been using my savings..." Non-regular Workers at Large Corporations Left Behind from Government Support].' Nishinihon Shimbum, 23 September. Accessed 15 February 2021. https://www.nishinippon.co.jp/ item $/ \mathrm{n} / 646635 /$.

Toyo Keizai Online. 2020. "Korona shitsugyō" reikoku ni kirisuterareru hitobito no sakebi [People's Voice Against the Cruel Cases of "Coronavirus Dismissals"].' livedoor NEWS, 22 June. Accessed 15 February 2021. https://news.livedoor.com/ article/detail/18453437/.

World Health Organization (WHO). 2020a. 'Shingata korona uirusu kansenshō: kankeisha muke tokusetsu peiji [COVID-19: Special Page for Interested Parties].' 21 August. https://extranet.who.int/kobe_centre/ja/covid/covid-technical.

—. 2020b. 'Covid-19 and gender.' Advocacy Brief, 14 May. https://extranet.who.int/ kobe_centre/sites/default/files/G43_20200514_JA_Gender.pdf.

\section{About the Author}

Saori SHIBATA, PhD, is an Assistant Professor at Leiden University. Her research focuses on Japan's political economy, including the changing nature of work, the digital economy, and how Japan's model of capitalism is transforming. This draws on institutionalist approaches to capitalism and critical political economy. She has published on these topics in journals such as New Political Economy and British Journal of Political Science. She is the author of Contesting Precarity in Japan: The Rise of Nonregular Workers and the New Policy Dissensus (Cornell University Press, 2020). 
